\title{
Return Migration of Nurses: A Concept Analysis
}

\author{
Ferry Efendi $^{1}$, Anna Kurniati², Eileen Savage ${ }^{3}$, Nursalam Nursalam ${ }^{4}$, Ah. Yusuf, Kusnanto Kusnanto ${ }^{5}$ \\ ${ }^{1}$ Lecturer, Faculty of Nursing, Universitas Airlangga, Surabaya, Indonesia; ${ }^{2}$ Health planner specialist, \\ Center for Planning and Management of Human Resources for Health, BPPSDMK, Ministry of Health, \\ Indonesia; ${ }^{3}$ Professor, School of Nursing, University College Cork, Ireland; ${ }^{4}$ Professor, ${ }^{5}$ Lecturer, Faculty \\ of Nursing, Universitas Airlangga, Surabaya, Indonesia
}

\begin{abstract}
Background: Return migration is a complex, challenging phenomenon and to date it remains a concept that is not well understood. A concept analysis would help to clarify what is meant by return migration. This paper aims to report on an analysis of the concept of return migration of nurses.

Design: Concept analysis using the Walker and Avant approach.

Data Sources: Google Scholar, Pubmed, EBSCO, JSTOR and Web of Science databases were searched without a timeframe. Twenty-one articles meeting the inclusion criteria were included.

Method: This study employs eight steps of Walker and Avant's method to conduct the concept analysis.

Results: Return migration of nurses can be defined by five attributes: the motivation and decisions of migrant nurse, return as human right, resource mobilisation, reintegration and return itineraries. Antecedents of return migration include the economic, social, geographical, political, family and life cycle that comprise the cause and effect framework. With regards to return migration, the consequences are beneficial or detrimental depend on the point of view migrant nurses, source country, receiving country, nursing profession and country health system. Empirical referents have been identified and support potential area to undertake a research on return migration.
\end{abstract}

Conclusion: This concept analysis has clarified current understandings and enhance the clarity of return migration concept. It recognises the centrality of return as a component in migration stage that needs a comprehensive approach.

Keywords: concept analysis, return migration, nurse migration, brain gain.

\section{INTRODUCTION}

Migration of skilled health workers in a global context has increased significantly over the last two decades. ${ }^{1,2}$ Nurses as a large part of professional health care workforce have contributed to the significant flows of this migration movement. ${ }^{3-5}$ Migration has long been assumed as a one direction process ${ }^{6}$ such that migrants who emigrated would permanently stay in the destination country. However, there is increasing evidence showing that the migrants are returning to their country of origin known as return migration. ${ }^{7-9}$

Acknowledging the importance of return migration, The International Centre of Nurse Migration recognised this movement as a means of benefiting the countries of origin and called for serious attention. ${ }^{10}$ The International
Organization for Migration (IOM) also support this idea by emphasising on the need for comprehensive and cooperative approaches to managing return as a part of the human movement. ${ }^{11}$ The issue of return has become increasingly significant among immigrants although in the absence of statistical data. The study pointed out the need for global attention on the nurses' return migration that is highly complex and needs further action from nursing profession. ${ }^{10}$

Concept analysis as Walker and Avant (2005) has argued can provide a knowledge base to get a clear picture of phenomenon, object or idea. ${ }^{12}$ The aim of this concept analysis was to examine the concept of return migration as it is used in global nurses' migration, to provide a brighter understanding of the phenomenon and suggestion for future study can be developed and measured. 
Data sources: An electronic search using the keyword "return migration nurse", "return emigrant nurse", "return immigrants nurse" was undertaken using databases relevant to nursing, medicine and social sciences, Pubmed, EBSCO, JSTOR, Web of Science and Google Scholar.

Data Selection and Analysis: The final sample of 21 documents was selected with inclusion criteria for the selection of papers were: a) reported on migrants returning or having returned to their country of origin; and (b) focused on qualified nurses.

\section{RESULTS}

Uses of the concept in literature: There is no available definition of return migration from commonly referred dictionaries, Oxford and Merriam-Webster dictionary. The first definition of return migration proposed by Bovenkerk (1974) which define as the return of people after emigrating to origin country for the first time. ${ }^{13}$ Above terms have various interpretations. For example with regards to the movement, Dumont and Spielvogel (2008) define the movement as the initial migration only to be called return migration. ${ }^{14}$

\section{Defining attributes}

Motivation and decisions of nurse migrant: Individual motivation and decision for going back to the country of origin is one of key distinctive associated with return nurse migration. It has been argued that individual decision to return home as a response of personal factor, career path and others. ${ }^{15,10}$ Individual initiatives to return has been decided on the early stage of migration or during they stay in foreign country. ${ }^{16,17}$ Motivation to return home was reported influenced the willingness and readiness of migrant which consider the circumstances in both, home and host countries. ${ }^{18}$

Return as human right: Freedom of return under the umbrella of migration was described in the literature on return home. Recognising the significant mobility on health professional, the WHO issued the global code by recommending the Member States to take into account individual right to migrate and leave any country. ${ }^{19}$ Recalling resolution WHA57.19 in which the World Health Assembly requested the Director-General to develop a voluntary code of practice on the international recruitment of health personnel in consultation with all relevant partners; Responding to the calls of the Kampala Declaration adopted at the First Global Forum on Human
Resources for Health (Kampala, 2\u20137 March 2008 Back to the past, referring to the article 13 section 2 of The Universal Declaration on Human Rights stated that "Everyone has the right to return to his country". ${ }^{20}$ The positions statement by International Council of Nurses (2007) recognise the potential benefit of migration and call for support to nurse who wishes to return home by putting the nurses right on priority.

Resource mobilization: Bringing resources back to the countries of origin marked the character of return migration. Nurse returnees not only bringing the financial capital but also human and social capital. ${ }^{10}$ It is undeniable that the flow of remittances to the low and middle- income countries plays a significant role in the nation's development. ${ }^{21}$ Even though we are a lack of data on the impact of remittances from nursing workforce, evidence showed that in Philippine as a source country of nurses share $10 \%$ remittances of Gross Domestic Product, $14 \%$ for Jamaica and $8.5 \%$ for Uganda. ${ }^{22}$ Brain gain is the most expected of returned migrants which brings new skill, knowledge and idea to contribute to the advancement of their origin's country. ${ }^{23}$ Studies of return migration in Jamaica and Pacific Island countries described that most returnees have gained new or additional capabilities. ${ }^{21,16}$

Reintegration: Return migration was characterised by reintegration phase into the family, group and society in his or her country. Reintegration found quite complex, dynamic and challenging aspect of return migration. ${ }^{11}$ Reintegration to be influenced by situation and condition in both countries. ${ }^{24}$ When migrants feel that they have achieved their goals, they are more ready to reintegrate into the home country. ${ }^{18}$ Complex reintegration problems have been investigated by Arowolo for instance joblessness, social maladjustment, boredom and frustration among non-nurses migrants. ${ }^{25}$ This study consistent with research of nurses migrant who returns to Indonesia, the majority of nurses were unemployed and faced difficulty in building a career. ${ }^{26}$

Return itineraries: The journey of return was complex which generally divided into voluntarily and involuntarily. These types were explained in the literature of return migration of nurses. Majority the studies support the benefits of voluntarily return as a form to contribute in the nation development. ${ }^{27}$ Voluntary return due to the completion of work contract, and goals achievement was reported by another study. ${ }^{16}$ However, some study also noted that forced return migration might become the push factor from country of residence to make them back home. ${ }^{10}$ 
Model case of return migration of nurses: In the Walker and Avant method, model case was constructed to further clarify the concept. The case may be derived from our real life, invented or found in published document. ${ }^{12}$ A model case adapted from return migration study in which exist in real life context.

Sumiati (Pseudonym) is a 28 years old who hold a bachelor's degree in nursing. She has been working in Japan for three years as foreign nurses. Working as nurses in Japan allows her to earn around 2000 USD per month, eight times higher than Indonesia. Having this wage, she was thinking to return home after she reaches her personal goals. She also sent the money back to home country for her family. After Tsunami disaster hit Japan in 2011, her family was worried about her safety and tried to persuade her for return. Even though she has passed the Japanese Nursing Examination and eligible to stay in Japan for unlimited periods, finally she decided to go back to Indonesia and tried to find a new job. While waiting for the job interview, she was running a small business from the saving money in Japan. She was shocked to find out that living in her city was challenging and difficult to find a job. She thought that she must rebuild her career from zero as a new nurse.

All attributes arise in this case describe the complexity of the concept. Sumiati demonstrated individual motivation in her decision to return home. Her return was influenced by the achievement of her personal goals, crisis, and her family. Financial capital was obviously observed from her situation to support her family and herself at home country. Lastly, return home positioned her on the difficulty finding a job and struggles to seek a new vacancy for her future.

Additional cases: related case: There is one case related to return migration concept of which have some attributes of return migration but actually different. Following is an example of related case.
Denias (Pseudonym) was left his job to migrate to Australia because of the war happened in his home country. After arriving in Australia, the immigration office found him without a legal document. Only two months ahead of his arrival date, the Australian government has decided to deport him back to his country of origin.

Denias case only has one attribute, his return itinerary was forced by the state to expel from the host country (involuntary return migration). This type of return repeatedly showed by refugees and asylum seekers that flow to developed countries.

Antecedents: The cause and effect model is the most prevalent framework for explaining return migration of nurses. ${ }^{10}$ The antecedents for return migration of nurses are social, economic, geographical, political, family or life cycle. ${ }^{6}$ Cause and effect factors drive nurses to return to the country of origin which affected by circumstances in the host and home country. ${ }^{6}$ Economic motives for example when the job arrangement reaches the end of the contract, it might be a cause factor to leave host country. ${ }^{8}$ On the other side, enough saving in country of origin might become an effect factor to return home. Noneconomic consideration also having more influenced for return home than economic reason. ${ }^{6}$

Consequences: Mount evidence showed the positive and negative impact of return migration on various players on this movement. ${ }^{10}$ The players include migrant nurses, nursing profession, host and home country. For instance, developing countries who have a surplus of nursing workforce could gain benefit for the return of migrant nurses. The brain gain is much more expected than brain drain particularly from the middle and lowincome countries.

Table 1: Concept on return migration of nurse: antecedent, attributes and consequences

\begin{tabular}{|c|c|c|}
\hline Antecedents & Attributes & Consequences \\
\hline $\begin{array}{c}\text { Drivers influencing motivation to } \\
\text { return (cause and effect) }\end{array}$ & $\begin{array}{c}\text { Motivation and decisions of nurse } \\
\text { migrant }\end{array}$ & $\begin{array}{c}\text { Beneficial and detrimental } \\
\text { depending on: }\end{array}$ \\
\hline Social & Return as human right & Individual \\
\hline Economic & Resource mobilization & Reurce country \\
\hline Geographical & Reintegration & Nursing profession \\
\hline Political & Return itineraries & National health system \\
\hline Family/Life Cycle & & \\
\hline
\end{tabular}


Empirical referents: Measuring return migration can be challenging as there is still confusion on the definition and data availability as well. ${ }^{28}$ How was country dealing with this issue by lack of system to track the returnee obviously appeared on the published literature. ${ }^{29}$ Mostly country relies on the census, survey, population registries, labour force survey, country social survey, and data from employment services. ${ }^{28}$ A study from most developed countries conveys a message that there is a need of established tools to measure the return migration.

The attributes, antecedents and consequences of return migration of nurses can be scrutinised using mixed methods, either quantitative or qualitative. The need to develop instrument or scale to measure return migration is necessary particularly for the standard measurement among countries to allow greater understanding of this issues.

\section{DISCUSSION}

In this concept analysis, the discourse of return migration on nurses has been elaborated in the systematic approach with implication on nursing research, education, and practice. According to this analysis, we need a specific scale to measure this phenomenon in standard ways. This study also highlights that return migration in nursing societies is occasionally approached in a holistic manner. International organisation in nursing has proposed a position statement on the important aspect addressing the global nurse migration..$^{30}$ In the global connectedness and interdependence between countries on the issues of migration, return issue will become more prevalent.

A concept analysis of return migration was challenging in the absence of available data, particularly on nursing perspective. By this, nursing profession needs to take action by implementing some measures to deal with the underlying problem.

\section{CONCLUSION}

This article provides an analysis of the concept of return migration of nurses found in published literature. The analysis proposed that return migration of nurses has been identified as having characters: individual's motivation and decision, universal human right, resource mobilisation, reintegration and return itineraries. Countries involved in this program should promote orderly and regulated return migration of nurses using a comprehensive approach.
Conflict of Interest: Authors declared that we have no conflict of interest.

Acknowledgment: None

Source of Funding: NA

Ethical Clearance: NA

\section{REFERENCES}

1. Connell, J. \& Buchan, J. The impossible dream? Codes of practice and the international migration of skilled health workers. World Med. Heal. policy 3, 1-17 (2011).

2. Wismar, M., Maier, C. B., Glinos, I. A., Dussault, G. \& Figueras, J. Health professional mobility and health systems. Evidence from 17, (World Health Organization, 2011).

3. Buchan, J. \& Aiken, L. Solving nursing shortages: a common priority. J. Clin. Nurs. 17, 3262-3268 (2008).

4. Efendi, F., Chen, C.-M., Nursalam, N., Indarwati, R. \& Ulfiana, E. Lived experience of Indonesian nurses in Japan: A phenomenological study. Japan J. Nurs. Sci. 13, 284-293 (2016).

5. Efendi, F., Nursalam, N. N., Kurniati, A. \& Gunawan, J. Nursing qualification and workforce for the Association of Southeast Asian Nations Economic Community. Nurs. Forum 1-6 (2018). doi: $10.1111 /$ nuf.12243

6. King, R. Generalizations from the history of return migration. Return Migr. Journey hope or despair 7-55 (2000).

7. Blouin, C. \& Debnath, P. CARICOM return migration and brain circulation: case study of Caribbean-born nurses. Can. Foreign Policy J. 17, 101-114 (2011).

8. Kurniati, A., Chen, C.-M. M., Efendi, F. \& Ogawa, R. A deskilling and challenging journey: the lived experience of Indonesian nurse returnees. Int. Nurs. Rev. n/a-n/a (2017). doi:10.1111/inr.12352

9. Efendi, F. et al. IJEPA: Gray Area for Health Policy and International Nurse Migration. Nurs. Ethics 24, 313-328 (2015).

10. Haour-Knipe, M., Davies, A. \& ICNM. Return Migration of Nurses. 2015, (International Centre on Nurse Migration, 2008). 
11. IOM. Return Migration: Challenges and Opportunities. 2015, (2008).

12. Walker, L. O. \& Avant, K. C. Strategies for theory construction in nursing. (Appleton \& Lange Norwalk, CT, 2005).

13. Bovenkerk, F. The sociology of return migration: a bibliographic essay. (Martinus Nijhoff, 1974).

14. Dumont, J.-C. \& Spielvogel, G. Return migration: A new perspective. Organ. Econ. Coop. Dev. (OECD), Int. Migr. Outlook, Annu. Rep. (2008).

15. Brown, Connel, J., Brown, R. P. C. \& Connell, J. The migration of doctors and nurses from South Pacific Island Nations. Soc. Sci. Med. 58, 21932210 (2004).

16. Thomas-Hope, E. Return Migration to Jamaica and its Development Potential. Int. Migr. 37, 183207 (1999).

17. Troy, P. H., Wyness, L. A. \& McAuliffe, E. Nurses' experiences of recruitment and migration from developing countries: a phenomenological approach. Hum. Resour. Health 5, 15 (2007).

18. Cassarino, J.-P. Theorising return migration: The conceptual approach to return migrants revisited. Int. J. Multicult. Soc. 6, 253-279 (2004).

19. World Health Organization. User's guide to the WHO global code of practice on the international recruitment of health personnel. 2014, (2010).

20. United Nations. Universal declaration of human rights. 2015, (1948).

21. Brown, R. P. C., Connell, J., Brown \& Connell, J. Occupation-specific analysis of migration and remittance behaviour: Pacific Island nurses in
Australia and New Zealand. Asia Pac. Viewp. 47, 135-150 (2006).

22. ICNM. International Nurse Migration and Remittances. 2015, (2007).

23. Ammassari, S. \& Black, R. Harnessing the potential of migration and return to promote development: applying concepts to West Africa. (International Organization of Migration, 2001).

24. Adzei, F. A. \& Sakyi, E. K. Drivers of return migration of Ghanaian health professionals: Perspectives from doctors and nurses in urban Ghana. Int. J. Migr. Heal. Soc. Care 10, 102-120 (2014).

25. Arowolo, O. O. Return migration and the problem of reintegration. Int. Migr. 38, 59-82 (2000).

26. Efendi, F. et al. Return migration of Indonesian nurses from Japan: Where should they go? $J$. Nurs. Educ. Pract. 3, p154 (2013).

27. Lorenzo, F. M. E., Galvez-Tan, J., Icamina, K. \& Javier, L. Nurse migration from a source country perspective: Philippine country case study. Health Serv. Res. 42, 1406-1418 (2007).

28. Smoliner, S., Förschner, M., Hochgerner, J. \& Nová, J. Comparative Report on Re-Migration Trends in Central Europe. Re-Turn, Cent. Soc. Innov. Vienna 81 (2011).

29. Dustmann, C. \& Weiss, Y. Return migration: theory and empirical evidence from the UK. $B r . J$. Ind. Relations 45, 236-256 (2007).

30. ICN, FNIF \& Burdett Trust for Nursing. The Global Nursing Shortage: Priority Areas for Intervention. 2014, (2006). 